\title{
European Security in the 1990s
}

Deterrence and Defense after the INF Treaty 

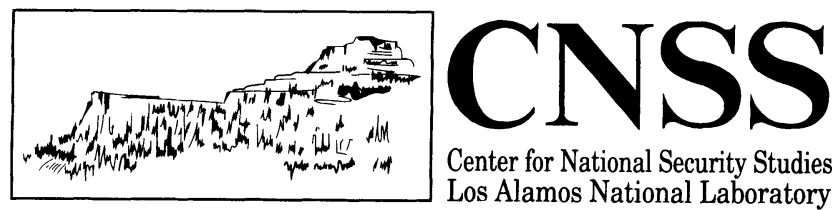

\section{ISSUES IN INTERNATIONAL SECURITY Series Editors: Robert E. Pendley and Joseph F. Pilat}

BEYOND 1995: The Future of the NPT Regime

Edited by Joseph F. Pilat and Robert E. Pendley

EUROPEAN SECURITY IN THE 1990s: Deterrence and Defense after the INF Treaty

Walter Laqueur and Leon Sloss

A Continuation Order Plan is available for this series. A continuation order will bring delivery of each new volume immediately upon publication. Volumes are billed only upon actual shipment. For further information please contact the publisher. 


\section{European Security in the 1990s}

\section{Deterrence and Defense after the INF Treaty}

\section{Walter Laqueur}

Center for Strategic and International Studies

Washington, D.C.

and

Leon Sloss

Leon Sloss Associates

Washington, D.C.

With the assistance of Philipp Borinski

Foreword by

David M. Abshire

SPRINGER SCIENCE+BUSINESS MEDIA, LLC 


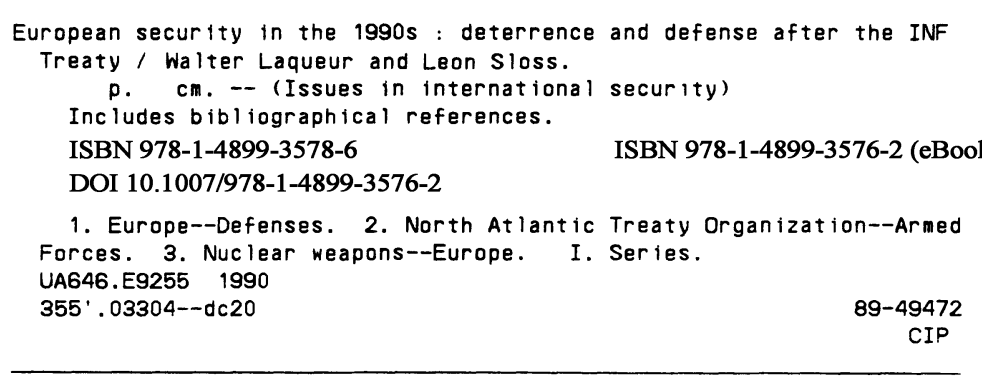

This series of books has been prepared as an account of work sponsored by the Los Alamos National Laboratory. Neither Los Alamos National Laboratory, any agency thereof, nor any of their employees makes any warranty, expressed or implied, or assumes any legal liability or responsibility for the accuracy, completeness, or usefulness of any information, apparatus, product, or process disclosed, or represents that its use would not infringe privately owned rights. Reference herein to any specific commercial product, process, or service by trade name, mark, manufacturer, or otherwise does not necessarily constitute or imply its endorsement, recommendation, or favoring by the United States Government or any agency thereof. The views and opinions of authors expressed herein do not necessarily state or reflect those of the United States Government or any agency thereof.

(C) Springer Science+Business Media New York 1990

Originally published by Plenum Press, New York in 1990

Softcover reprint of the hardcover 1st edition 1990

\section{All rights reserved}

No part of this book may be reproduced, stored in a retrieval system, or transmitted in any form or by any means, electronic, mechanical, photocopying, microfilming, recording, or otherwise, without written permission from the Publisher 


\section{The Center for National Security Studies}

The Center for National Security Studies (CNSS) is a studies and analysis organization of the Los Alamos National Laboratory. Drawing on the broad knowledge at Los Alamos of science and engineering relevant to national security issues, the Center's research focuses on the interaction between technology and policy and on developing insights that may improve the relationship between the development of new technology and the achievement of national policy goals.

The principal mission of the Center is to promote and conduct long-term research and analysis in the broad areas of defense policy and arms control, focusing in particular on the requirements for technology that derive from trends in national and international security policy. In addition, it helps Los Alamos management and technical staff better address national defense needs by providing insight into national security policy, strategy, and technology issues, and by assisting in Laboratory long-range planning. The Center also provides a forum for the exchange of ideas on international security issues among Laboratory personnel, government agency staffs, university faculties, and interested citizens.

To implement its programs and activities, the Center supports an interdisciplinary staff, drawing on expertise from the social sciences, including history and political science; the physical and biological sciences; engineering; and mathematics. The Center conducts an active visitor and consultant program. It encourages short- and long-term visits by experts from government and private institutions and by university faculty members.

The Center sponsors seminars, workshops, and conferences designed to bring Los Alamos personnel into contact with outside experts and to stimulate broader discussion of the relationships between technology and U.S. defense policy. The Center also acts to enhance communication between Los Alamos and other organizations, such as colleges and universities, that are studying issues of interest to the Laboratory.

The publications program of the Center is intended to communicate the results 
of studies to Laboratory personnel and to reach a wider policy analysis community in government, military, and academic circles, as well as private industry. Central to the publications program is this book series, Issues in International Security. The volumes in the series are based on research conducted by the Center's staff and by internationally recognized experts working with the CNSS. A primary goal of the series is to promote the reasoned analysis of international security issues, with emphasis on how these issues shape and are shaped by technological developments. 


\section{Foreword}

Rarely if ever have the political, economic, and military foundations of the Western Alliance been in such a state of flux. Walter Laqueur and Leon Sloss, therefore, deserve credit not just for the quality of the analysis in this superb book but also for the timeliness of its appearance.

As Laqueur says in his chapter "Touring the Western European Defense Horizon," if the likely development of European defense policies is not particularly reassuring, at least it gives no grounds for despair. The list of problems we face is a daunting one. First there is the spiralling cost of defense expenditures, particularly in the absence of significant NATO or inter-European cooperation. This is particularly serious in light of the reluctance to increase, or even maintain, current expenditures in the midst of Mikhail Gorbachev's "peace offensive" and the extraordinary changes in Eastern Europe, both of which have had a dramatic impact on Western public opinion.

There is also a problem in the perceived relative economic decline of the United States vis-à-vis Western Europe and Japan, which only exacerbates calls to reduce the number of American troops in Europe. Other dangers to the political cohesion and military credibility of the alliance include demographic trends that threaten current manpower levels, transatlantic acrimony over the burden-sharing issue, and political pressures (particularly in West Germany) toward denuclearization and even neutralism.

To address all of these elements, and more, requires a mixture of vision, strategy, and political skills. As Laqueur says, "a new strategic concept is needed both for the individual countries and for NATO as a whole."

Even though the situation with West Germany is radically new, it has a precedent in the mid-1960s. Back then, General de Gaulle lost faith in NATO's nuclear strategy and in U.S. dominance, declared that the USSR was no longer a threat, and withdrew from the military side of the alliance. It all sounds suspiciously like Germany today. But in response to de Gaulle, NATO acted admirably by producing the Harmel Report, which articulated the policy of defense and dialogue that has been NATO's guiding star ever since. 
Then, while I was at NATO in 1983, we had a different kind of crisis. Following the stalemate caused by the Soviet walkout from negotiations, an EastWest study set up by Leo Tindemans laid the groundwork for NATO's successful pursuit of the "Treaty between the United States of America and the Union of Soviet Socialist Republics on the Elimination of Their Intermediate-Range and ShorterRange Missiles."

The momentum of the Cold War was broken when the Soviets tried and failed to split NATO on the issue of deploying intermediate-range nuclear weapons. In response, in a masterful diplomatic move, Moscow reversed course. If Stalin had created NATO by his threats, Gorbachev would unmake it by removing that threat. As a result of the General Secretary's deft diplomatic maneuvering, NATO moved from victorious unity in 1983-1984 to potentially dangerous disunity.

NATO's current disarray means that despite the promise of change in the Soviet Union, there is new peril in Europe. As the USSR is confronted by destabilizing forces-some springing from its own "new thinking"- the West confronts its own forms of destabilization. The result is a transformation of Europe in which the Soviet threat has diminished but the dangers of instability have increased. In the 1990s, with the Soviet empire crumbling, Eastern Europe moving to liberate itself, intensified interest in German reunification, the withdrawal of American troops, transatlantic protectionism, and economic conflict, the Western security system could disintegrate. At worst, this could lead to the types of uncertainties and miscalculations that produced World War I. Even in a less pessimistic scenario, however, there will still be a breakup of the Cold War order, and a questioning of some of NATO's fundamental tenets that accompanied that order. It is now necessary for NATO to follow these earlier precedents but with a more comprehensive mandate to develop a NATO grand strategy for the 1990s.

The first aspect of this should be an attempt to do what NATO has resisted doing before, namely, examining the critical triangular relationship between contentious short-range nuclear forces (SNF), improvements in conventional forces, and negotiations for nuclear and conventional arms control. If short-range nuclear forces have any use, it is to offset, however crudely, the Warsaw Pact's conventional superiority. But if the conventional balance can be stabilized through a combination of NATO force improvements and conventional arms control agreements, then the requirements for modernizing SNF could be reconsidered.

We have, therefore, the makings of an alliance deal. The American proposal, which makes SNF negotiations contingent on conventional reductions and insists in advance that SNF will not be reduced to zero, identifies some of these trade-offs correctly. However, what is still lacking is any link between SNF and the third side of the triangle, namely, improvements in NATO's conventional forces. Consequently, there is a pressing need for an overall net assessment of our critical vulnerabilities, caused not just by superior Soviet forces but also by flagrant weaknesses deriving from NATO's own maldeployments, ammunition shortages, and so forth.

One of this book's most valuable insights is its observation that NATO must develop systems "that can adapt to weapons perhaps not yet fully conceived." And 
although the authors do not identify such systems specifically, an excellent example of how we might close our self-created vulnerabilities would be the development of the most important Pentagon program of the past decade- "competitive strategies." Instead of matching the Warsaw Pact tank for tank, the concept emphasizes the incorporation of smart and brilliant weapons into new weapons systems and tactical concepts that might turn the tide of a conventional battle in NATO's favor. As well as rendering NATO's defense posture more effective, competitive strategies also provide an uncontroversial alternative to the deeply divisive short-range nuclear missiles. Political unity within the alliance is more important than any weapon system.

Discussions within the alliance at every level-from summit meetings to "public diplomacy"- are needed on a huge range of issues in order to convince Western electorates of the need to retain a credible defense posture. Walter Laqueur and Leon Sloss are fully aware that security involves not just military matters but politics and economics as well. It is this fundamental awareness providing a backdrop to their remarkable expertise and grasp of the details that makes this book such a welcome contribution to the debate.

David M. Abshire

President, Center for Strategic and International Studies

Former Ambassador to NATO 


\section{Preface}

A specter is once again haunting Europe-the specter of profound political and economic change. These changes offer promise as well as peril, and their ultimate effects are as yet unknown. Their implications for European security have been debated by politicians, policy analysts, pundits, and publics throughout Europe and the United States, and have created or exacerbated differences within the Atlantic Alliance. Contentious issues such as burden-sharing and short-range nuclear force modernization, along with the challenges of Mikhail Gorbachev's public diplomacy, pose a threat to the future of the alliance. And NATO's responsiveness to the political explosion in Eastern Europe, with its implications for East-West relations, will pose a fundamental challenge to the continued importance of the alliance for European security.

Will the Atlantic Alliance survive the challenge posed by the dramatic changes now occurring in Eastern and Western Europe? Are there viable alternatives to NATO? How will Europeans define and ensure their security in the years ahead? Will the apparent lessening of the Soviet threat preclude the need for costly and politically divisive decisions on defense budgets and force improvements?

The distinguished authors address these and other questions about European defense. They give particular attention to economic and demographic trends and to the attitudes of publics and political elites in the major countries of Western Europe. They also examine the implications of the Intermediate Nuclear Forces Treaty for the future of NATO; identify trends toward denuclearization and their meaning for European defense, which ultimately has relied on U.S. nuclear weapons for more than four decades; and explore the viability of alternative defense concepts for future European security. The compelling analysis provided in the volume is supported by an appendix containing an extensive collection of documents pertaining to European security.

In compiling the documents presented in the appendix, we acknowledge and appreciate the assistance of the United States Arms Control and Disarmament Agency; the United Nations Department for Disarmament Affairs; the British Information Services, New York; and the German Information Center, New York. We 
also acknowledge and appreciate the dedication and contributions of Center for National Security Studies staff. Arthur Nichols, the Center's editor, established with the publisher editorial procedures and schedules, and he copyedited the volume. Molly Cernicek's contributions were substantial—she played a critical role in collecting, preparing, and organizing the documents in the appendix. The skilled assistance of Janis Dye was indispensable in preparing the manuscripts for the publisher. And Wanda Franks deserves special recognition for facilitating our communications with the authors.

Joseph F. Pilat

Robert E. PENDLEy 


\section{Contents}

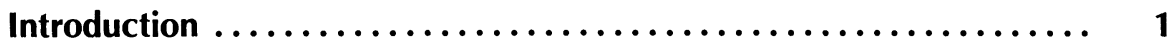

NATO's Dual-Track Decision $\ldots \ldots \ldots \ldots \ldots \ldots \ldots \ldots \ldots \ldots . \ldots \ldots$

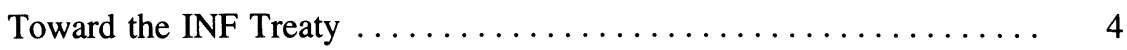

In the Aftermath of the INF Treaty $\ldots \ldots \ldots \ldots \ldots \ldots \ldots \ldots, 6$

1. Touring the Western European Defense Horizon $\ldots \ldots \ldots \ldots \ldots . .9$

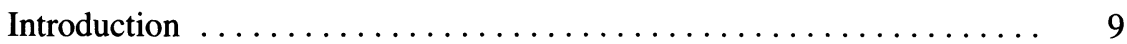

West Germany and the Atlantic Alliance in the Years to Come ...... 10

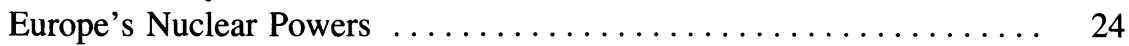

The Benelux Countries and Scandinavia $\ldots \ldots \ldots \ldots \ldots \ldots \ldots . . \ldots \ldots$

NATO's Southern Flank ....................... 37

Soviet Foreign Policy and the Future of NATO $\ldots \ldots \ldots \ldots \ldots \ldots, 41$

Notes and References $\ldots \ldots \ldots \ldots \ldots \ldots \ldots \ldots \ldots \ldots \ldots, 42$

2. Western European Defense: The Next Ten Years $\ldots \ldots \ldots \ldots \ldots .45$

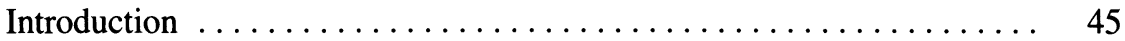

European Defense Cooperation $\ldots \ldots \ldots \ldots \ldots \ldots \ldots \ldots \ldots \ldots \ldots$

Alternative or Nonprovocative Defense $\ldots \ldots \ldots \ldots \ldots \ldots \ldots \ldots .54$

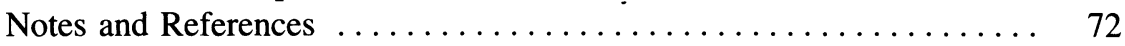

3. Future Requirements for Theater Weapons in Western Europe ... 75

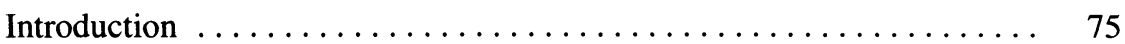

Setting the Context: Factors Affecting Theater Nuclear Forces ...... 77 
Future Requirements for Theater Nuclear Forces $\ldots \ldots \ldots \ldots \ldots \ldots 88$

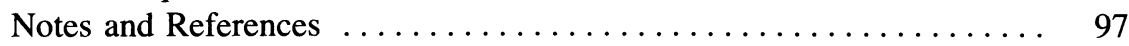

\section{Appendix: European Security in the Postwar Period: Documents from 1948-1989}

The North Atlantic Treaty Organization $\ldots \ldots \ldots \ldots \ldots \ldots \ldots \ldots \ldots, 103$

The North Atlantic Treaty, August 24, 1949 .............. 103

North Atlantic Council Communiqué, December 14, $1967 \ldots \ldots \ldots \ldots .105$

Speech of M. Laurent Fabius, September 17, $1982 \ldots \ldots \ldots \ldots \ldots \ldots .107$

North Atlantic Council Communiqué, December 9, $1983 \ldots \ldots \ldots \ldots 111$

Lord Carrington, Secretary General, on the Alliance,

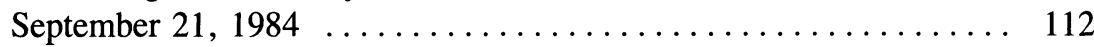

The Security Policy of the Federal Republic of Germany, 1985 . . . . 117

Maintaining Security in a Changing World [United Kingdom, 1988] . . 120

Declaration of the Heads of State and Government, March 2-3, 1988 ............................ 124

Statement on the Ministerial Meeting of the North Atlantic Council,

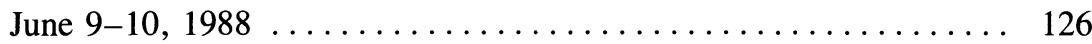

European Security Cooperation $\ldots \ldots \ldots \ldots \ldots \ldots \ldots \ldots \ldots \ldots \ldots, 128$

Treaty between Belgium, France, Luxembourg, the Netherlands, and the United Kingdom, March 17, $1948 \ldots \ldots \ldots \ldots \ldots \ldots \ldots$

Protocols to the 1948 Brussels Treaty, October 23, $1954 \ldots \ldots \ldots \ldots \ldots 132$

Franco-German Summit Statement, February 27-28, 1986 . . . . . . . 139

Speech by Sir Geoffrey Howe, March 16, 1987 . . . . . . . . . . 140

Arms Control: The Intermediate-Range Nuclear Forces Treaty ..... 145

Treaty between the USA and USSR, December $8,1987 \ldots \ldots \ldots \ldots 145$

Address by FRG Chancellor Helmut Schmidt, October 28, 1977 .... 161

Communiqué of a Special NATO Meeting, December 12, 1979 ..... 165

President Ronald Reagan's Speech to the United Nations General

Assembly, September 26, $1983 \ldots \ldots \ldots \ldots \ldots \ldots \ldots \ldots \ldots . \ldots \ldots$

NATO Nuclear Planning Group Communiqué, October 28, $1983 \ldots \ldots 166$

Speech by FRG Chancellor Helmut Schmidt to the SPD Conference,

November 19-20, $1983 \ldots \ldots \ldots \ldots \ldots \ldots \ldots \ldots \ldots \ldots . \ldots \ldots$

Statement by General Secretary Andropov, November 24, $1983 \ldots \ldots .169$

Communiqué of the North Atlantic Council, June 11, $1987 \ldots \ldots \ldots .170$ 
NATO Nuclear Planning Group Communiqué, November 1987 . . . . . 171

North Atlantic Council Ministerial Communiqué, December 1987 . . . . 172

Arms Control: Short-Range Nuclear Missiles ............... 176

Statement by British Foreign and Commonwealth Office,

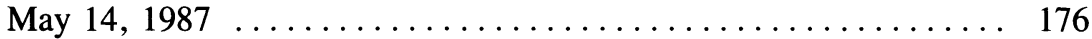

NATO Nuclear Planning Group Communiqué, May 15, 1987 . . . . . 176

Statement by the Government of the Federal Republic of Germany,

June $2,1987 \ldots$. . . . . . . . . . . . . . . . . . . . . . . . . . . . . . . . . . 177

Arms Control: Conventional Forces $\ldots \ldots \ldots \ldots \ldots \ldots \ldots \ldots \ldots, 179$

Document of the Stockholm Conference, September 19, 1986 . . . . . 179

Address of the Warsaw Treaty Member States, June 11, $1986 \ldots . . . . .184$

Press Conference of François Mitterrand, April 23, 1987 . . . . . . . 186

Interview with Jacques Chirac, May 16, $1987 \ldots \ldots \ldots \ldots \ldots \ldots$

Halifax Statement on Conventional Arms Control, May 30, 1987 . . . 187

Conventional Arms Control: The Way Ahead, March 2-3, $1988 \ldots \ldots .188$

Mikhail Gorbachev's Address to the United Nations,

December 7, $1988 \ldots \ldots \ldots \ldots \ldots 1$

Statement Issued by the North Atlantic Council,

December 8-9, $1988 \ldots \ldots \ldots \ldots \ldots \ldots . \ldots \ldots \ldots$

Mandate for Negotiation on Conventional Armed Forces in Europe, January 10, $1989 \ldots \ldots \ldots \ldots$. . . . . . . . . . . . . . . . . . . 195

Position Paper, March 6, 1989 ....................... 196

Conceptual Framework of Agreement on Conventional Armed Forces

in Europe, March 9, 1989 . . . . . . . . . . . . . . . . . . . 199

Speech by Hans-Dietrich Genscher, April 27, $1989 \ldots \ldots \ldots \ldots \ldots 2$

President George Bush's Statement, May 29, 1989 . . . . . . . . . . 205

About the Authors $\ldots \ldots \ldots \ldots \ldots \ldots \ldots \ldots \ldots \ldots \ldots \ldots \ldots \ldots \ldots \ldots$

Index $\ldots \ldots \ldots \ldots \ldots \ldots \ldots \ldots \ldots \ldots \ldots \ldots \ldots \ldots \ldots \ldots \ldots, 209$ 